\title{
Using Narrative Fiction as a Means of Assessing and Learning in a History of Social Welfare Module
}

\author{
Jonathan Parker ${ }^{1} \&$ Harry Farmer ${ }^{2}$
}

\section{Introduction}

This paper reports a pilot assessment project in which Sociology \& Social Policy students were asked to write, as a group, a fictional narrative concerning one of a number of characters set within one of a choice of time periods.

Students were able to decide on the character, setting and story from a range of lecturer-provided scenarios and time periods which reflected many of the key areas covered in lecture and seminar classes. The knowledge to be uncovered by the project brief aligned with the summative assignment for the module. Students were expected, in their narratives, to identify and make explicit reference to legislation, social policy information and sociological/anthropological concepts pertinent to the period and chosen character. They were also advised to draw upon reading of literature contemporary to the period and the characters chosen in a way that would inform their narratives and help them develop a credible plot and storyline. A 2-3,000 word fictional narrative was to be produced by each group covering the period in the character's life denoted by their age and situation.

The project was assessed in a formative way but did not attract marks towards the summative assignment for the module. However, all students taking this core module played an active part in the construction of the narratives and encouraged to consider aspects of meta-learning including how they can work with others and cooperate as a member of a team. Students who undertook this module gained a rich and deep understanding of social welfare, policy and sociological understandings of the human condition that could be transferred to other aspects of the students' degree, despite some feeling aggrieved that the work attracted no marks. As a result of the pilot's success, the project has been developed into the core mode of assessment for this module in the future.

Advantages and disadvantages of the narrative assessment are reported, examples provided, and suggestions made for the future use of this mode of assessment.

\section{Narrative in learning, teaching and assessment}

There is a wealth of education-based literature concerning narrative assessment. Whilst most of this relates to teaching and learning in primary, secondary and special needs teaching in school settings, it has relevance for higher education and for this pilot in particular.

In New Zealand, the Ministry of Education (2009) have produced guidance to integrate narrative assessment into special needs teaching to help teachers develop a deeper sense of pupils' abilities, pupils' and teachers' perceptions of self, living

\footnotetext{
${ }^{1}$ Professor of Society and Social Welfare, Department of Social Science and Social Work, Bournemouth University, UK parkerj@bournemouth.ac.uk; jonathancrabtreeparker@gmail.com ${ }^{2}$ Undergraduate student, Sociology and Social Policy, Department of Social Science and Social Work, Bournemouth University, UK
} 
contexts and possibilities for creating innovative teaching and learning experiences. The work builds on Black and Williams (1996) understanding of teaching and learning as an interactive process driven by everyday classroom practices and the interactive process acts as a platform for assessment. It also employs Carr's (1998a, b, 2001) work that used learning stories as a form of narrative assessment. This work, however, focused on teacher-written stories that sought to assess the aspirations of learners and to assess the learning that had been achieved. In later work, still concerned with school-based teaching and learning practices, Cowie and Carr (2003) argue that narratives of learning underpin notions of ownership of that learning process whilst legitimising the socio-cultural contexts in which that learning takes place. This is somewhat similar to Ødeggaard and Pramling's (2013) study in which collaborative narratives are developed between preschool children and teachers as a means of making and sharing meaning.

The findings of school-based research on narrative learning and assessment is important for the higher education context in which this project was based. The potential to create innovative and interactive ways of learning, developing a sense of ownership, locating the learning process within its socio-cultural context and providing a means for assessment were all important to the project. However, it went deeper than this to consider aspects of meta-learning, including understanding how students worked in their groups, what roles they played, where their comfort-zones were and how these were challenged.

Narratives have been developed as learning tools in higher education. Critical event narratives have been used in assessing quality in higher education (Mertova and Webster, 2014). In our earlier research, concerning the learning of inter-cultural competences, we employed the development of critical incident narratives, which although biographical used a storied approach to the collection of data that were analysed against diaries (Parker et al. 2012, 2014; Ashencaen Crabtree et al. 2012, 2014, 2015). This pursued a two-fold purpose of research and learning and assessment.

Szurmak and Thuna (2013) describe the use of narratives in learning and teaching librarian skills. They acted on the premise that narratives embed both the details whilst they establish knowledge about larger-scale structures and contexts. They use 'mind, brain, education' (MBE) science which is interested in how the neural processes in the brain translate learning experiences into learning behaviours and allow for the construction of rich and meaningful learning environments.

Szurmak and Thuna (2013) state that narratives are different to stories, which are linear, whereas narratives are representations of events or series of events. They draw upon Polkinghorne's (1995) understanding of the importance of plot within narratives, 'emplotted narratives' (p. 547). These narratives are a tool for making sense of the world or an 'act of meaning' (Bruner, 1990) that demonstrates interaction, process and change.

Narrative research is a well-trodden, increasingly popular and yet diverse area of inquiry. Alongside Polkinghorne's championing of the method as a research tool, Carr (1986), Riessman (1993), Clandinin and Connelly (2000) highlight its importance in constructing understanding and meaning in social life, and Hamui Sutton (2011) 
specifically focuses on meaning-making through narratives of suffering. It is also used in the education of teachers as well as in assessing the learning potential and teaching and learning activities for teachers (Connelly and Clandinin, 1987, Conle, 2000). Mayo (2001) adapts the form to construct life-story narratives in teaching lifespan developmental psychology in higher education settings.

Taken together these approaches underpin the development of the method for this module. As a History of Social Welfare module students study the development of social protection, security and welfare through an examination of the British Poor Law system and its earlier ecclesiastical and religious underpinnings, exploring other countries also. This is taken through to the creation and evolution of the British Welfare State and its replication and alternative developments in other countries. The knowledge constructed through these examinations are finally taken thematically to interrogate similarities and differences in welfare in contemporary austerity society. So, the conception of narrative forms as an assessment of learning is designed to show the students' capabilities in creating meanings and locating these within the contexts, both literary and historical, of specific time periods. Importantly, it allows the students to get the sense of the 'human' side of welfare need, something that can be embedded in contemporary explorations as well as historical ones. Thus, the method rests within a robust axiological cradle, taken as an imperative in nurturing deep critique of the history of social welfare provision.

\section{The study process}

At the outset to the module the students were presented with the details of the project. This was explained in class but also detailed within an online module guide. It was emphasised that completion of the project was not an assessed part of the module itself but that it was an expectation that all students would participate and contribute to the development of the narrative within their allotted student groups. Of course, it is difficult to ensure such expectations are adhered to. It was not possible to write the project into the assessment because of a lack of time to put the project through the necessary modification panels. However, it was explained that this would act as a robust means of testing the suitability of this as an innovative and creative methods of assessment for future students.

The project brief outlined the focus as writing, as a group, a fictional narrative of one of a number of characters, shown below:

a. a young unmarried woman (about 19 years old) and her infant child (about one year old)

b. an older clerical worker (63 years old) in ill-health

c. a 15 year old orphan (girl or boy)

d. a disabled person (you decide on the age, gender and disability)

e. a foreign refugee family (focusing on one member in particular)

Each of the groups were expected to define and explain the details as the fictional account was produced. The chosen character was to be placed in one of the following time periods:

i. $\quad 1830 \mathrm{~s}-1850 \mathrm{~s}$ post Poor Law (Amendment) Act Britain

ii. $\quad 1920$ s Britain 


$$
\begin{array}{ll}
\text { iii. } & 1960 \text { s Britain } \\
\text { iv. } & 1980 \text { s Britain } \\
\text { v. } & 21^{\text {st }} \text { century Britain }
\end{array}
$$

These periods had been covered in lectures and seminars throughout the module and reading and information was available as a means of beginning the students' explorations. Students were given the following brief:

When composing your story you should identify and make explicit reference to legislation, social policy information and sociological/anthropological concepts pertinent to the period and character. For instance you may wish to make reference to elements of the Poor Law (Amendment) Act, how it was perceived by the general public, what its impact may have been upon the way people behaved, organised their lives and so forth.

The students were also pointed towards key elements of literature of the periods from which they could choose their characters. Much of this is available now from online 'free' sites such as 'project gutenberg' (https://www.gutenberg.org). However, care was necessary to ensure that copyright was preserved and we also included hard copies, especially of newer books. An example of the literature used is given below from well-known nineteenth century sources, although less known sources were also indicated to widen student's familiarity with the period. As the time periods moved forward we did direct students to other forms of media such as film, and plays and we will be seeking to introduce a greater range of alternative media including music as the method matures.

Draw, also, on your reading of literature contemporary to the period and the character. The following may be particularly relevant but should not be considered exclusive:

\section{Charles Dickens}

Oliver Twist http://www.gutenberg.org/ebooks/730

Little Dorrit http://www.gutenberg.org/ebooks/963

(The Personal History of) David Copperfield

http://www.gutenberg.org/ebooks/43111

Hard Times http://www.gutenberg.org/ebooks/786

Nicholas Nickleby http://www.gutenberg.org/ebooks/967

\section{Benjamin Disraeli}

Coningsby http://www.gutenberg.org/ebooks/7412

Sybil http://www.gutenberg.org/ebooks/3760

Tancred http://www.gutenberg.org/ebooks/20004

\section{Frances Hodges Burnett}

A Little Princess http://www.gutenberg.org/ebooks/37332

\section{The process}

Time was allocated within lecture and seminar time for the student groups to discuss and begin to develop the narrative, but there was also an expectation of self-directed 
learning time to undertake further background reading and narrative construction and refinement.

The students were organised in groups of six to eight people. The groups were not arranged by the lecturing staff despite past experience of challenges of student selfselection. In contemporary higher education the selection and working practices of self-directed groups raises a range of concerns to be addressed. Given the fee and student loan structures in England and Wales almost two thirds of students work to supplement their income (Endsleigh, 2014). Thus making arrangements to meet, work and develop self-directed learning projects becomes more complex. This is something that was considered when in designing this method. Students were asked early in the module to develop their groups and communicate names, characters and time periods to lecturing staff and a brief was developed to lead students through the production of narratives, a set of milestones to chart progress.

The following information was provided to students to guide their group work and self-directed study:

Make sure, in your narrative, that you include references to your reading of literature, newspapers of the period and (auto)biographical accounts of people's lives. (Also, as with any assessed academic assignment, add your reference list at the end of the narrative for your peers to follow up should they so wish.)

You may also wish to use the process of developing the fictional accounts as a way of ensuring you are gaining the learning you need to complete your assessed assignment, and to check that you are meeting the learning outcomes.

The fictional narrative should be about 2-3,000 words in length, flexible to suit your needs to tell the story and demonstrate your learning. It should cover the period in the character's life denoted by their age and situation, but you can refer back to experiences they may have had previously, showing knowledge of the social and welfare policy of the period.

What happens in your story should accurately reflect what may have happened and should detail the social and welfare situation of the day, the philanthropic and charitable thought and the ways in which society was organised at that time.

These details outlined the expectations and emphasised some of the important aspects of learning that were involved, anticipating some of the questions that may be raised in completing a piece of work that would not contribute to the overall mark for the module. The meta-learning that attaches to such work was highlighted, and, again, attention was paid to some of the instrumental thinking that is seen in contemporary higher education and the employability skills element was made explicit alongside the deep learning that is possible from immersion into the narratives of a particular character and timeframe. 
The project is non-assessed in that it does not accrue a mark nor does it count towards your degree classification, but all students taking this core module are expected to play an active part in the construction of the narratives as this will provide opportunities for demonstrating how you can work with others and cooperate as a member of a team - a skill that many employers are seeking, and something that can be commented on in references if shown. It will also help you to identify some of the ways in which you work best.

Students will gain from developing a rich and deep understanding of social welfare, policy and sociological understandings of the human condition. This learning can be transferred to other modules in your degree.

Alonsgide developing the work in groups wider learning was encouraged by sharing and presenting the narratives across the student cohort. Again, this allowed those involved to demonstrate presentational skills, production skills and so on according to their own strengths. The students were interrogated as to their own chosen roles and their comfort zones with an expectation of reflection on these.

Once the narratives have been developed the groups will be expected to place them on the shared space on $M y B U$ for the other groups to read and comment upon. Discussion of all the narratives will take place towards the end of the module and an informal peer-ranking will be conducted.

Planning and executing the narratives

The way the students worked together as a group was left to each group and its members to determine, including the allocation of responsibilities for the various elements of the project. It was suggested to the groups that they make an agreement between themselves early in the process. This was designed to form part of the metalearning associated with the activity, as a means of assisting the students to gain a deeper understanding of the ways in which they work best and how they work with others. This represented a 'low-cost' way of facilitating this kind of skills learning so important in enhancing student employability, it was embedded in the academic learning and teaching activities of the module.

In order to help the student groups plan their work a suggested guideline that delineated a timescale and plan was offered to the students:

Week One: Get to know each other in your group. Decide what life situations you are interested in and what time period you think would best address the learning for this project.

Agree on the character and time period.

Outline your future workplan for subsequent weeks.

Week Two: Agree on the key elements for your narrative. What action takes place and why; what social structures have an impact on the characters and the story; what legislation, social welfare policies and understandings of social life will be relevant. Construct an initial 'working plan' or storyboard that sets out the central themes for the narrative. 
Agree individual and group responsibilities for researching the elements of the narrative.

Weeks Three \& Four: Research your areas and check with your group that the narrative is progressing according to plan or revise as necessary.

Week Five (READING WEEK): Use this time to consolidate the developing narrative so far. Write a first draft and identify the policies, laws, social understandings of life and history that underpin the narrative. Address any inconsistencies and determine what refinements need to be undertaken.

Weeks Six and Seven: Research revisions. Redraft the narrative. Check the references. Double check for historical accuracy, coherence and reality. Agree and write your final draft. Upload final draft onto $M y B U$ site.

Week Eight: Share and comment on each others' narratives. Supportive analysis and peer review.

This project was evaluated in terms of the perceived learning and development of the students through the use of fictional narratives. Student consent was sought by lecturing staff to write up the experience of this mode of teaching and learning for academic and pedagogical publication and for sharing more widely as an example of enhancing the learning process.

\section{The narratives}

Five narratives were developed and presented. Alongside them being uploaded to the virtual learning platform MyBU, a Blackboard based VLE, the students were asked to prepare and deliver a presentation to their class mates on their narrative and on their learning. Each group was different in the way they interpreted the project brief and in the ways in which they delivered the presentation.

Characteristics relating to the narratives are contained in the table below:

\begin{tabular}{|c|c|c|c|c|c|}
\hline & $\begin{array}{l}\text { Chosen } \\
\text { character }\end{array}$ & Time period & $\begin{array}{l}\text { Additional } \\
\text { information } \\
\text { regarding } \\
\text { learning } \\
\text { experience }\end{array}$ & References & $\begin{array}{l}\text { Word } \\
\text { count } \\
\text { (circa) }\end{array}$ \\
\hline Group 1 & $\begin{array}{l}\text { a young } \\
\text { unmarried } \\
\text { woman (about } \\
19 \text { years old) } \\
\text { and her infant } \\
\text { child (about } \\
\text { one year old) }\end{array}$ & $19^{\text {th }}$ Century & Verbal & No & 1500 \\
\hline Group 2 & $\begin{array}{l}\text { a foreign } \\
\text { refugee family } \\
\text { (focusing on }\end{array}$ & $21^{\text {st }}$ Century & Verbal & Yes & 3000 \\
\hline
\end{tabular}




\begin{tabular}{|c|c|c|c|c|c|}
\hline & $\begin{array}{l}\text { one member in } \\
\text { particular) }\end{array}$ & & & & \\
\hline Group 3 & $\begin{array}{l}\text { a } 15 \text { year old } \\
\text { orphan (girl or } \\
\text { boy) }\end{array}$ & $19^{\text {th }}$ Century & $\begin{array}{l}\text { Written } \\
\text { submission and } \\
\text { verbal }\end{array}$ & $\begin{array}{l}\text { Additional } \\
\text { information } \\
\text { referenced, } \\
\text { narrative not } \\
\text { referenced }\end{array}$ & 2000 \\
\hline Group 4 & $\begin{array}{l}\text { a young } \\
\text { unmarried } \\
\text { woman (about } \\
19 \text { years old) } \\
\text { and her infant } \\
\text { child (about } \\
\text { one year old) }\end{array}$ & $20^{\text {th }}$ Century & Verbal & Referenced & 2000 \\
\hline Group 5 & $\begin{array}{l}\text { Alternative } \\
\text { choice - } \\
\text { wartime } \\
\text { evacuee }\end{array}$ & $20^{\text {th }}$ Century & Verbal & Referenced & 3000 \\
\hline
\end{tabular}

All narratives included key social policies and legislation and set these within the social and human contexts of the age in which they were set. The narratives allowed students to demonstrate affective appreciation of the experiences of their characters. Of course, some of this was necessarily anachronistic but demonstrated some of the emotive and empathic rationale underpinning the production of social welfare whilst recognising changing socio-political instrumentalities within the legislation guiding these constructions. The narratives showed, at times, some misunderstandings of the periods in which they were set and of social policies at that time. However, this was useful as a formative exercise in highlighting those areas that caused difficulties and to ensure that learning could be reinforced.

Most of the groups entered enthusiastically into the task, allotting roles, forming methods of working that were feasible for group members. There was an issue with one group in which some of the members took no active part and highlights the need for clearly published expectations of student commitment to learning and teaching tasks. The narratives followed the brief except in two cases - in group one where no references were provided and in group five where characters were adapted to suit the interests of the group. This was possible because the project work did not attract a mark but reflected a need for academic staff to ensure that assignment briefs are clear and explicit in the future. This has been addressed by developing a system of the coproduction of assignment briefings. Academic staff share the initial brief and rubric with students on the module, students share their understandings of this and amendments are made until a refined assignment brief that is clearly understood is reached.

All groups reflected on the learning they had gained throughout the project, recognising that group working skills allowed them to act as a tam and to take on aspects of the work that played to their strengths. There was a degree of enjoyment in the project and the presentation of the stories to classmates allowed the groups to flourish. It was interesting to observe the emotional impact the stories made both on classmates observing but also within and amongst the groups presenting their stories.

\section{Discussion and ways forward}


There is a broader concern in contemporary higher education relating to its function and goal, and in respect of the aspirations of students and reasons why they study. The focus on assessment, outcome and achievement is well documented and is indicative of a changing instrumental focus within universities with which academics appear to have colluded.

Some of the students were unhappy at undertaking academic work for which they received no mark. This was despite clear explanations at the start of the module and an emphasis on the importance the narrative had for building a database from which the assessed question could be answered. Matters of learning and academic literacy of a subject were considered secondary to the instrumental function of completing an assessment and achieving a desired outcome.

On a more positive note some students explicitly noted the ways in which their learning had taken place, how the development of the narratives had connected with the overall aims of the module and how the project interlinked with their Sociology \& Social Policy degree programme as a whole. As a result, the project is being written in to the assignment brief for the module in the next academic year working on the basis that it offers a chance to develop deep learning of the subject area and attendant skills and if it is not assessed people will not do it to the best of their abilities or, sometimes, not at all.

Not everyone talks an equal part in the groups and this is a matter that needs addressing through explicit expectations and means of allocating marks differentially according to input but without disadvantaging people.

Where people engage with both subject and meta-learning the results can be profound. It can enliven the social policies and sociological understanding of the time and it can introduce a new generation to literature. However, the last point is something that requires some work. One group, in particular, developed a narrative around a deep appreciation of nineteenth century literature, especially Dickens. Indeed, they managed to inject a degree of humour and satire into the story that echoed some of Dickens' work. However, whilst literature was suggested as a means of providing insights into the lives of people in the periods studied, it was often not overtly used or referred to. It appears important to ensure that the importance of literature for understanding historical times is highlighted more effectively.

Abstract learning is not always possible and an interactive approach demands greater levels of engagement with the subject. The ways in which students dealt with the narratives demonstrated a growing politicisation, something which underlies much debate around social welfare and its reform. We would recommend more work to be conducted on interactive, assessed learning that co-produced knowledge specific to a discipline such as social policy or sociology.

\section{References}

Ashencaen Crabtree, S., Parker, J., Azman, A. \& Carlo, D. P. 2012. Epiphanies and learning in a postcolonial Malaysia context: A preliminary evaluation of international social work placements. International Social Work. Advance Access doi:

$10.1177 / 0020872812448491$ 
Ashencaen Crabtree, S., Parker, J., Azman, A., Masu'd, F (2014) Sociological examination of student learning in children's services in Malaysia. Journal of Comparative Research in Anthropology \& Sociology. 5, 1.

Ashencaen Crabtree, S., Parker, J., Azman, A., Masu'd, F. (2015) Typologies of learning in international student placements, Asia Pacific Journal of Social Work and Development. Doi: 10.1080/02185385.2014.1003393

Black, P. and William, D. (1998). Inside the Black Box: Raising Standards through Classroom Assessment. London: King's College.

Bruner, J. (1990) Acts of Meaning, Cambridge: Harvard University Press.

Carr, D. (1986). Time, narrative, and history. Bloomington, IN: Indiana University Press.

Carr, M. (1998a). Assessing Children's Experiences in Early Childhood. Final Report to the Ministry of Education (Part One). Wellington: Ministry of Education.

Carr, M. (1998b). Assessing Children's Learning in Early Childhood Settings.

Wellington: NZCER. (three videos and a workshop booklet for practitioners)

Carr, M. (2001). Assessment in Early Childhood Settings: Learning Stories. London: Paul Chapman.

Clandinin, D.J., \& Connelly F.M. (2000). Narrative inquiry: Experience and story in qualitative research. San Francisco, Jossey-Bass.

Conle, C. (2000). Narrative inquiry: Research tool and medium for professional development. European Journal of Teacher Education, 23(1), 49-63.

Connelly, F.M., \& Clandinin, D.J. (1987). On narrative method, biography and narrative unities in the study of teaching. Journal of Educational Thought, 21, 130139.

Cowie, B. and Carr, M. (2003). "The Consequences of Sociocultural Assessment in Early Childhood Settings: Community, Competence and Continuity". In A. Anning, J. Cullen, and M. Fleer (eds), Early Childhood Education: Society and Culture (pp. 95106). London: Sage.

Endsleigh (2014) Endsleigh, NUS student survey, available at http:/hub.endsleigh.co.uk/2014/careers/is-a-part-time-job-at-uni-a-necessity/, accessed June 2015.

Hamui Sutton, L. (2011) Las narrativas del padecer: una ventana a la realidad social, Revista Cuicuilco, 18 (52): 51-70.

Mayo, J.A. (2001) Life analysis: Using life-story narratives in teaching life-span developmental psychology, Journal of Constructivist Psychology, 14 (1): 25-41. 
Mertova, P. and Webster, L. (2014) Critical event narrative inquiry in Higher Education quality, Quality Assurance in Higher Education, 3 (2): 15-21.

Ministry of Education (2009) Narrative Assessment: A guide for teachers, Wellington, NZ, Learning Media Ltd, available at http://www.throughdifferenteyes.org.nz/_data/assets/pdf_file/0010/57925/NarrativeAssessment a-guide-for-teachers.pdf, accessed June 2015.

Ødeggaard, E.E. and Pramling, N. (2013) Collaborative narrative as linguistic artefact and cultural tool for meaning-making and learning, Cultural-Historical Psychology, $2,38-44$.

Parker, J., Ashencaen Crabtree, S., Baba, I., Carlo, D. P. and Azman, A., 2012. Liminality and learning: international placements as a rite of passage. Asia Pacific Journal of Social Work and Development, 22:3, 146-158.

Parker, J. Ashencaen Crabtree, S., Azman, A., Carlo, D.P., Cutler, C. (2014) Problematising international placements as a site of intercultural learning European Journal of Social Work, advance access, http://dx.doi.org/10.1080/13691457.2014.925849

Polkinghorne, D.E. (1995) Narrative configuration in qualitative analysis in J. Amos Hatch and R. Wisniewski (eds) Life History and Narrative, London: Routledge.

Riessman, C.K. (1993). Narrative analysis. Newbury Park, CA, Sage. 